\title{
Studi Interaksi Masyarakat Masa Lampau Suatu Analisis Model Graviti (Gravity Model)
}

\section{Slamet Sujud Purnawan Jati}

Keywords: method, theory, practices, analysis, settlement, pattern, model

\section{How to Cite:}

Purnawan Jati, S. S. (1999). Studi Interaksi Masyarakat Masa Lampau Suatu Analisis Model Graviti (Gravity Model). Berkala Arkeologi, 19(1), 78-88. https://doi.org/10.30883/jba.v19i1.794

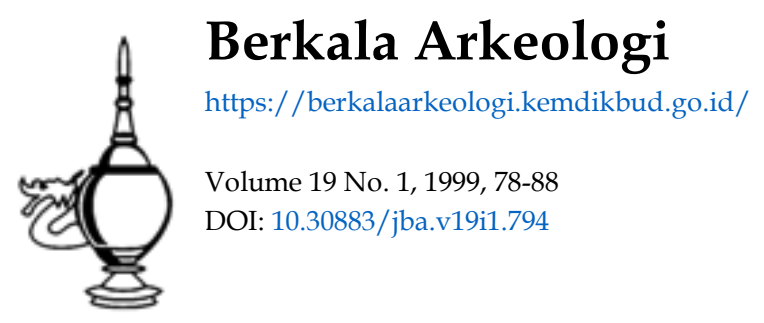

\section{c) (7) (2)}

This work is licensed under a Creative Commons Attribution-NonCommercial-ShareAlike 4.0 International License. 


\title{
STUDI INTERAKSI MASYARAKAT MASA LAMPAU \\ SUATU ANALISIS MODEL GRAVITI (GRAVITY MODEL)
}

\author{
Slamet Sujud Purnawan Jati \\ (Universitas Negeri Malang)
}

\section{Pendahuluan}

Banyak Antropolog telah memperkarakan bahwa perubahan kebudayaan harus dipahami tidak saja dalam terminologi suatu adaptasi masyarakat terhadap lingkungan fisik, namun juga pada lingkungan sosial. Selain itu, adanya kelangkaan suatu metode untuk menghasilkan informasi mengenai hubungan antara masyarakat masa lampau, menyebabkan perlu dikembangkan metode-metode baru yang dapat diandalkan. Metode baru tersebut harus diuji-coba terlebih dahulu. Oleh karena itu, maksud tinjauan ini adalah untuk mendiskusikan suatu prosedur yang telah dikembangkan untuk mengukur satu aspek dari lingkungan sosial, yaitu: intensitas interaksi antara masyarakat.

Para ahli antropologi, sejarah maupun arkeologi senang bekerja dengan data artefaktual (artifact). Artefak adalah benda hasil garapan tangan manusia masa lalu yang berupa budaya materi, baik berupa tembikar, alat batu, kapak besi, prasasti, nisan kubur, dan sebagainya. Para ahli berusaha membuat bagaimana artefak-artefak dan fragmennya tersebut dapat "berbisik-bisik", "berkata-kata", atau bahkan dapat "berteriak" kepada mereka, sehingga informasi dan rekonstruksi masa lalu dapat diketahui. Tentu saja hal ini tergantung pada kualitas dan kuantitas data, serta metode analisis yang digunakan. Dengan demikian akan banyak aspek dan perkara yang dapat diangkat dari data artefaktual ini, baik yang relevan dengan aspek ekonomi, sosial, politik, religi, dan teknologi, maupun yang relevan dengan perkara kronologi (time), morfologi (form), dan distribusi (space).

Salah satu upaya para ahli untuk merekonstruksi masa lalu adalah berusaha mengukur intensitas interaksi masyarakat, baik di antara ruang-ruang dalam suatu masyarakat (Longacre 1964, 1970, Hill 1970) maupun di antara masyarakat pada masa lampau (Longacre 1964, Wiley 1971). Mereka telah mendefinisikan interaksi antara lain sebagai gerakan dari individu-individu antara masyarakat-masyarakat, pertukaran wanita dalam perkawinan, pertukaran tembikar dan barang-barang ekonomi lainnya, atau sebagai "interaksi sosial sepanjang garis-garis kekurangannya, religi, dan politik" (Longacre 1970:38, Wiley 1971:4).

Upaya tersebut di atas diakukan dengan mengukur tingkat kesamaan atribut gaya, khususnya pola hias artefak (misal tembikar) pada setiap unit. Mereka berasumsi 
bahwa ranking pada pola hias tersebut dibagi oleh golongan-golongan atau masyarakat-masyarakat yang secara langsung sebanding dengan banyaknya interaksi antara unit-unit tersebut. Pola hias spesifik dengan arti ritual mungkin dihubungkan lebih dekat dengan kelompok rumah tangga tertentu daripada dengan kelompok lainnya. Para ahli telah mendasarkan pada prinsip bahwa dua daerah yang bersamasama menggunakan pola hias tembikar yang sama adalah lebih dekat berhubungan daripada dengan beberapa daerah yang lain. Akan tetapi mereka telah mengabaikan unsur jarak (range) dan unsur pola hias (design) yang digunakan pada tingkat subregional atau bahkan tingkat sub-desa. Oleh karena itu, dalam hal ini mendesak diperlukannya teknik statistik yang kompleks.

Problema terbesar dari metode tersebut adalah bahwa hubungan antara intensitas interaksi dan kesamaan gaya telah begitu saja diterima daripada dibuktikan. Oleh karena itu, pada kesempatan ini akan diintrodusir suatu model pendekatan dari Stephen Plog. Dalam hal ini, Plog mencoba mengintrodusir model graviti atau model gaya beray (gravity model) untuk memprediksi dengan akurat kuantitas interaksi antara desa-desa di suatu lembah tertentu. Plog akan membuktikan bahwa para ahli antropologi, sejarah, dan arkeologi dapat menguji hal yang dapat dipercaya dari ukuran interaksi mereka sendiri dengan menggunakan data dari masyarakat masa lampau. Model ini dilakukan dengan akurat dan bermanfaat, serta dapat dimodifikasi oleh penemuan-penemuan baru di masa lampau.

\section{Rumusan Model Graviti (Gravity Model)}

Studi Stephen Plog (1976) sebenamya merupakan kritik dan sekaligus pembuktian dari analisis terdahulu yang kontroversial dari studi James F. Deetz (1965), William A. Longacre (1970), dan James N. Hill (1970), yang dianggap kurang dapat dipercaya. Pandangan waktu itu adalah bahwa ada hubungan antara atribut-atribut gaya (stylistic) dengan kelompok-kelompok keluarga (garis keturunan) di Pueblo, bagian barat Amerika. Lebih ekstrim lagi, berdasarkan analisis tembikar dikatakan bahwa para wanita adalah pembuat tembikar prasejarah, yang mengidentifikasikan lokasi matrilineal spesifik (garis keturunan ibu) di daerah Pueblo.

Akan tetapi berdasarkan hasil studi Plog, pandangan tersebut ternyata tidak benar. Bahkan Plog sendiri mengajukan hipotesis terbaru yang hendak diuji. Hipotesis yang didasari oleh asumsi bahwa ukuran kesamaan gaya (stylistic) merefleksikan intensitas interaksi. Oleh karena itu rumusan hipotesis berbunyi "bahwa kesamaan gaya menjadi ukuran interaksi masyarakat sehingga koefisien kesamaan akan berbanding langsung dengan populasi masyarakat dan berbanding terbalik dengan jarak antara masyarakat". 
Dengan demikian model yang telah dirumuskan dan dintrodusir oleh Stephen Plog (1976:256) bertujuan untuk memprediksi dengan akurat ukuran interaksi antara masyarakat, dan direncanakan untuk mengetahui interaksi yang sebenarnya. Model yang lebih sederhana dan lebih umum ini disebut graviti. Model ini mengemukakan bahwa banyaknya interaksi antara dua masyarakat adalah berbanding langsung dengan populasinya dan berbanding terbalik dengan jarak antara mereka. Model ini sering dinyatakan dengan rumus:

$$
L_{i j}=\frac{P_{i} P_{j}}{D_{i j}^{b}}
$$

\section{Keterangan :}

$\mathrm{L}_{\mathrm{ij}} \quad$ = banyaknya interaksi yang diprediksi antara tempat $\mathrm{i}$ dan tempat $\mathrm{j}$

$\mathrm{P}_{\mathrm{i}} \mathrm{P}_{\mathrm{j}} \quad$ = populasi dari dua tempat

$\mathrm{D}_{\mathrm{ij}} \quad=$ jarak yang memisahkan dua tempat

b = eksponen (pangkat) dari beberapa nilai terpilih

\section{Beberapa Penerapan Model Graviti}

Dalam evaluasinya dari model graviti, Olsson (1970:227-228) menemukan bahwa koefisiensi korelasi antara prediksi-prediksi dari model graviti dan data interaksi sebenarnya adalah tinggi dan secara statistik sangat berarti, tetapi koefisien regresi berubah-ubah. Oleh karena itu ia menyimpulkan bahwa kekuatan prediksi dari model graviti adalah tinggi, tetapi kekuatan eksplanatori adalah rendah (Olsson 1970:228). Morril (1963:82) telah menyatakan bahwa model graviti tersebut telah dicocokkan dengan banyak pengmatan dari distribusi jarak (migrasi) yang secara statistik cukup baik dan dapat dipercaya.

Stephen Plog akan membuktikan bahwa model graviti tersebut valid untuk sat ini, akan tetapi ada alasan mempercayai atau tidak sah untuk masa lampau. Hal ini akan tampak pada hubungan antara interaksi dan jarak. Jarak mempunyai pengaruh mengurangi interaksi saat ini. Dengan demikian, hal ini berpengaruh pada interaksi di masa lampau, apalagi bila levelnya dengan berjalan kaki, akan menjadi bahkan lebih besar.

Namun demikian, ada beberapa data yang dapat mendukung penggunaan model graviti ini. Studi Deetz dan Dethlefsen tentang gaya batu nisan di New England menunjukkan bahwa kepopuleran suatu gaya selama periode 1720-1760 berkurang dengan adanya jarak makam yang semakin jauh dari tempat kediaman si pemahat batu. Renfrew (1969:157) telah mempublikasikan distribusi obsidian di Timur Dekat 
yang menunjukkan suatu pengurangan obsidian pada himpunan (assemblage) dari suatu situs yang semakin jauh jaraknya dari sumber daya obsidian. Demikian pula analisis Pires-Ferreira pada tahun 1973 tentang pertukaran obsidian dihubungkan dengan kepadatan dan distribusi populasi, serta jarak dari sumber daya obsidian. Akhirnya Warren (1969) telah mempelajari distribusi tembikar di daerah Pueblo di lembah Rio Grande, yang menunjukkan bahwa proporsi barang-barang Tongue berkurang dengan adanya penambahan jarak yang semakin jauh dari Tongue Pueblo.

Data-data studi ini mendukung berlakunya model graviti, meskipun kebanyakan bukti mengenai hubungan antara interaksi dan jarak. Wright dan Zeder (1973) telah membuktikan tentang hubungan langsung antara populasi dan interaksi. Akan tetapi ukuran populasi itu dianggap konstan, terutama dalam analisis Warren dan Rewfrew, dengan asumsi bahwa ukuran himpunan artefak (assemblage) adalah dihubungkan secara langsung dengan ukuran populasi situs.

\section{Perkara Aplikasi Model Graviti}

Meskipun ini telah memberi kesan bahwa model graviti tampak menjadi suatu model interaksi manusia yang dapat dipercaya, ada beberapa perkara dalam penerapannya. Pertama, masalah mengenai ukuran jarak. Konsepsi orang terhadap jarak tidak selalu sama dengan jarak fisik atau alam (Hagget 1965:38). Bahkan Olsson (1965:26) telah mencatat satu asumsi model graviti, yaitu bahwa intensitas interaksi akan berkurang secara simetris dalam semua arah terhadap jarak. Akan tetapi pada kasus migrasi, bidang asimetris telah ditemukan. Ia telah menunjukkan bahwa presepsi seorang migran terhadap jarak adalah fungsi central place hierarchy (1965:39). Dalam studinya tentang migrasi orang Sedia, ia menggunakan jarak "fungsional" yang diukur dengan sejumlah daerah-daerah yang ikut campur tangan di antara dua tempat daripada oleh jarak fisik (1965:9).

Jika presepsi migran terhadap jarak adalah suatu fungsi dari central place hierarchy, mungkin tidak ada problema dalam analisis data di daerah Grasshoper, Hay Hollow Valley, dan Chevelen Canyon di Arizona, karena ini adalah tidak mungkin bahwa beberapa central place hierarchy ada di tempat-tempat ini. Perkara ini mungkin lebih penting berkenaan dengan data dari Oaxaca, Meksiko, di mana presepsi seseorang terhadap jarak adalah suatu fungsi dari faktor-faktor yang lain, yaitu sebagai pengaruh sosial. Perkara ini adalah lebih sulit untuk dihadapi. Para arkeolog telah mencoba mengukur apa yang mereka sebut "jarak sosial" antara masyarakat arkeologi. Akan tetapi konsep ini "pada dasarnya menunjuk kepada intensitas interaksi antara kelompok-kelompok". Oleh karena itu, dengan metode yang biasa digunakan untuk mengukur intensitas interaksi, mereka telah mengukur pula jarak sosial melalui kesamaan dari unsur gaya tersebut. 
Perkara kedua adalah bahwa jarak garis-lurus antara situs-situs arkeologi mungkin memberikan suatu alat yang tidak teliti bagi suatu perjalanan dari satu masyarakat ke masyarakat lainnya. Perkara ini dalam suatu daerah jarak dekat pada suatu masyarakat tampaknya tidak berpengaruh pada intensitas interaksi. Hal ini biasa disebut "plateau effect" (Olsson 1966:17), dengan catatan bahwa plateau effect terjadi terutama dalam jarak kurang dari 5 mil (Warren 1969).

Perkara ketiga dalam penerapan model graviti adalah bahwa intensitas interaksi dipengaruhi sejumlah variabel dalam populasi dan jarak. Sebagai contoh, penilaian adanya perubahan-perubahan intensitas interaksi terhadap jarak disebabkan faktorfaktor kelompok okupasi dari migran, tingkat masyarakat migran pada central place hierarchy, periode waktu dari interaksi, dan tujuan dari perjalanan (Olsson 1965:3131; 1966:16).

Studi Flannery (1968) pada pertukaran artefak olmac telah menyarankan faktor tambahan yang mungkin mempengaruhi instensitas interaksi. Ia mengusulkan bahwa intensitas interaksi di daerah-daerah perdagangan olmec ternyata tidak dipengaruhi oleh jarak, tetapi oleh adanya golongan elite lokal yang dapat mempertinggi status mereka melalui interaksi dengan olmec, terutama untuk daerah pertanian dan daerah yang potensi demografinya tinggi (1968:106). Dalam hal pertukaran meliputi barangbarang status tinggi, di mana daerah tersebut didiami oleh orang dengan standar kebutuhan, cita rasa, dan kontak yang sama (Olsson 1965:26).

Atas dasar data ini, Plog menganjurkan bahwa para ahli dapat menguji kesamaankesamaan gaya (atau pola hias) sebagai suatu ukuran interaksi melalui penggunaan prediksi model graviti. Tes tersebut akan didasarkan pada asumsi bahwa model graviti adalah valid. Jipotesis akan hal ini adalah bila kesamaan-kesamaan gaya menjadi ukuran interaksi masyarakat, maka koefisien kesamaan akan berbanding langsung dengan populasi masyarakat dan berbanding terbalik dengan jarak antara mereka (Plog 1976:256).

\section{Contoh Uji Interaksi Masyarakat}

Beberapa tes interaksi masyarakat dengan model graviti antara lain telah dilakukan di Hay Hollow Valley di Arizona, dengan cara menghitung kesamaan frekuensi kategori warna keramik. Studi yang sama dilakukan pula di Chevelon Canyon di Arizona terhadap pecahan-pecahan tembikar berupa fragmen badan, fragmen mangkuk, dan fragmen kendi atau guci berdasarkan unsur-unsur pola hiasnya. Di samping itu juga studi frekuensi gaya pada dua tipe tembikar pinedale black-on-white dan fourmile polychrome di Grasshopper Arizona. 
Berikut akan disampaikan suatu contoh penerapan model graviti pada interaksi antara desa-desa formatif di lembah Oaxac . Pada tahun 1971-1972, Plog telah mempelajari pola hias keramik atau tembikar dari lima desa di lembah Oaxaca, Meksiko. Jarak rata-rata yang memisahkan desa-desa ini adalah 13,1 mil, dengan simpangan baku adalah 7,3 mil.

Lebih dari $90 \%$ tembikar dari tiap-tiap desa berasal dari ekskavasi. Dalam studi ini Plog hanya menggunakan pecahan bibir (rim) dan pola-pola hias mangkuk, serta bejana-bejana yang berhias. Tipe tembikar yang digunakan dalam analisis Oaxaca adalah Atoyac yellow-white, suatu barang rumah tangga yang biasa digunakan pada sebagian besar produksi mangkuk dengan berbagai bentuk, dan tak disangsikan dibuat di tempat tersebut. Atoyac yellow-white adalah variasi Oaxaca dari tipe tembikar yang tersebar luas yang mempunyai variasi-variasi lokal.

Tembikar Atoyac yellow-white berdasar rata, berdinding tebal, seringkali dihias dengan pola hias gores (incised design). Kebanyakan pola yang paling umum adalah suatu bingkai garis-garis pararel yang memenuhi bagian dalam tepat di bawah bibir (rim). Kadangkala satu garis dipisah oleh motif free-standing kecil. Ini disebut hiasan "double-line-break" yang menyebar luas di Mesoamerika pada periode waktu itu, yang mempunyai ratusan variasi.

Di Oaxaca, tipe ini mulai dalam frekuensi rendah selama fase San Jose (1150-850 BC), mencapai puncaknya antara 900 dan $700 \mathrm{BC}$, dan turun selama bagian akhir fase Guadalupe ( $850-600 \mathrm{BC})$. Dua tipe utama tembikar yaitu bejana pola hias gores (incised design) dan mangkuk silindrik dengan hias gores pada bagian luar dan mangkuk terbuka dengan hias gores pada bagian dalam. Kedua bejana ini mungkin banyak digunakan untuk menghidangkan makanan, terutama untuk pelayanan satu individu.

Kesamaan dalam pilihan-pilihan pola hias antara situs kemudian diukur dengan alat koefisien Brainerd-Robinson dan Pearson's r, seperti yang dikerjakan pada data dari Southwetern United States. Nilai-nilai koefisien situs Oaxaca ditunjukkan pada dua kolom terakhir tabel 1 berikut (Plog 1976:267). 
Tabel 1. Koefisien Brainerd-Robinson dan Pearson's $r$ untuk unsur-unsur pola hias tembikar Atoyac yellow-white pada lima desa di Oaxaca.

\begin{tabular}{||l|c|c|c|c|c|}
\hline Pasangan situs & $\begin{array}{l}\text { Jumlah unsur } \\
\text { yang terjadi } \\
\text { per pasangan } \\
\text { situs }\end{array}$ & $\begin{array}{l}\text { Jarak antara } \\
\text { pasangan situs } \\
\text { dalam mil }\end{array}$ & $\begin{array}{l}\text { Estimasi } \\
\text { populasi per } \\
\text { pasangan situs } \\
\text { dalam rumah } \\
\text { tangga }\end{array}$ & $\begin{array}{l}\text { Koefisien } \\
\text { Brainerd- } \\
\text { Robinson }\end{array}$ & $\begin{array}{l}\text { Koefisien } \\
\text { Pearson' s r }\end{array}$ \\
\hline $\begin{array}{l}\text { - Fabrica San Jose- } \\
\text { San Jose Mogote } \\
\text { - Fabrica San Jose- } \\
\text { Huitzo } \\
\text { - Fabrica San Jose- }\end{array}$ & $264-94$ & 3,0 & $10-280$ & 83,67 &, 6364 \\
$\begin{array}{l}\text { Tierras largas } \\
\text {-Fabrica San Jose- } \\
\text { Abasolo } \\
- \text { San Jose Mogote- }\end{array}$ & $264-274$ & 10,8 & $10-10$ & 46,47 &, 2532 \\
$\begin{array}{l}\text { Huitzo } \\
- \text { San Jose Mogote- }\end{array}$ & $94-274$ & 7,2 & $10-10$ & 42,72 &, 2948 \\
$\begin{array}{l}\text { Tierras Largas } \\
\text { - San Jose Mogote- } \\
\text { Abasolo }\end{array}$ & $94-143$ & 17,6 & $10-10$ & 42,42 &, 5984 \\
$-\begin{array}{l}\text { - Huitzo Tierras } \\
\text { Largas } \\
- \text { Huitzo }\end{array}$ & $94-13$ & 18,4 & $280-10$ & 39,40 &, 1535 \\
$\begin{array}{l}\text { Abasolo } \\
- \text { Tierras Largas- } \\
\text { Abasolo }\end{array}$ & $274-143$ & 16,1 & $10-10$ & 19,89 &,- 0083 \\
\hline
\end{tabular}

Studi di lembah Oaxaca, dua desa yang menunjukkan kesamaan paling besar dalam pilihan pola hias adalah San Jose Mogote dan Fabrica San Jise (3 mil jaraknya; koefisien B-R 83,67 ). Dua desa yang menunjukkan paling sedikit kesamaan adalah Huitzo dan Abasolo (28,2 mil jaraknya; koefisien B-R 12,4).

Langkah selanjutnya dalam analisis tersebut adalah menentukan perkiraan kasar populasi pada setiap desa di Oaxaca sehingga model graviti dapat digunakan. Model graviti akan memprediksi bahwa interaksi pada suatu desa yang luas (1-3 ha) akan lebih besar daripada jauhnya jarak yang dapat dibandingkan. Hal ini tampak terutama sejak San Jose Mogote mempunyai suatu kompleks bangunan publik yang berbeda dengan yang ditemukan di Fabrica San Jose, Tierras Largas, ataupun kebanyakan desa-desa yang lebih kecil. Inilah yang mendorong interaksi. 
Langkah lain dalam analisis ini adalah menyusun (ranking) koefisien kesamaan, jarak antara situs, dan intensitas interaksi yang diprediksi. Susunan ini dapat ditunjukkan pada tabel 2 berikut (Plog 1976:267).

Tabel 2. Komparasi prediksi intensitas interaksi dengan kesamaan unsur-unsur pola hias pada lima desa di Oaxaca

\begin{tabular}{|l|c|c|c|c|}
\hline \multicolumn{1}{|c|}{ Pasangan situs } & $\begin{array}{c}\text { Ranking } \\
\text { atas dasar } \\
\text { jarak }\end{array}$ & $\begin{array}{c}\text { Prediksi } \\
\text { intensitas } \\
\text { interaksi }\end{array}$ & $\begin{array}{c}\text { Brainerd } \\
\text { Robinson }\end{array}$ & Pearson' s r \\
\hline Fabrica San Jose-San Jose Mogote & 10 & 1 & 1 & 2 \\
San Jose Mogote-Tierras Largas & 9 & 2 & 2 & 4 \\
Fabrica San Jose-Tierras Largas & 8 & 5 & 4 & 6 \\
San Jose Mogote-Huitzo & 7 & 3 & 7 & 8 \\
Fabrica San Jose-Huitzo & 6 & 6 & 3 & 7 \\
Tieras Largas-Abasolo & 5 & 7 & 8 & 5 \\
Huitzo-Tierras Largas & 4 & 8 & 9 & 10 \\
Fabrica San Jose-Abasolo & 3 & 9 & 6 & 3 \\
San Jose Mogote-Abasolo & 2 & 4 & 5 & 1 \\
Huitzo-Abasolo & 1 & 10 & 10 & 9 \\
\hline
\end{tabular}

Keterangan: $\quad{ }^{\mathrm{a}}$ Kolom satu merupakan urutan pasangan situs berdasarkan jarak dalam satuan mil; kolom dua adalah adalah untan intensitas interaksi yang diprediksi dengan model graviti; sementara kolom tiga dan empat berupa urutan pasangan situs dalam terminologi pola-pola hias pada tembikar Atoyac yellow-white yang diukur dengan koefisien Brainerd-Robinson dan Pearson's r.

Kovariasi dari koefisien kesamaan dengan jarak antar situs dan dengan intensitas interaksi yang diprediksi kemudian diukur menggunakan Spearman's r. Nilai ini ditunjukkan pada tabel 3 berikut (Plog 1976:268).

Tabel 3. Nilai Spearman's $r\left(r_{s}\right)$ untuk mengukur kovariasi di antara variabel-variabel seperti yang ditunjukkan dalam tabel 2 pada lima desa di Oaxaca ${ }^{a}$.

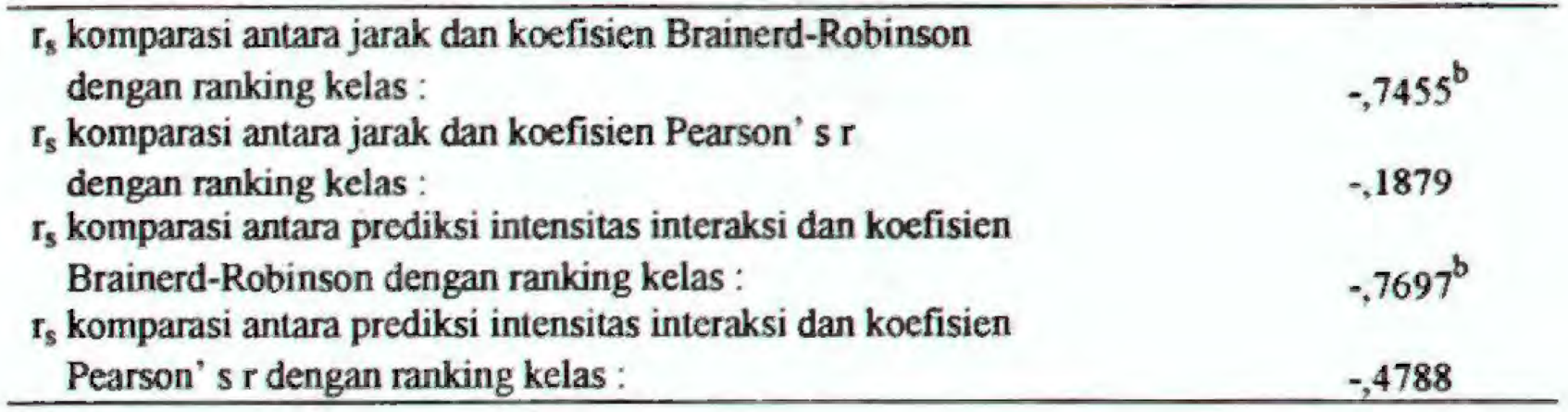


Keterangan: a Jarak antara pasangan situs, dan interaksi antara pasangan situs diprediksi dengan model graviti, dikomparasikan dengan ranking kelas pasangan situs atas dasar pembagian pola-pola hias pada tembikar Atoyac yellow-white, seperti dideterminasi oleh koefisien Brainerd-Robinson dan Pearson's r.

${ }^{\mathrm{b}}$ Secara statistik signifikan pada level,05.

Korelasi ranking dengan menggunakan koefisien Brainerd-Robinson sebagai suatu ukuran kesamaan secara statistik adalah signifikan pada level ,05. Kedua koefisien secara positif dikorelasikan dengan instensitas interaksi yang diprediksi dengan berdasar pada model graviti. Secara negatif dikorelasikan dengan jarak absolut antara situs. Fabrica San Jose dan San Jose Mogote, terletak hanya 3 mil jaraknya, diranking sebagai sangat mirip gayanya (1 dengan Brainerd-Robinson, 2 oleh Pearson's r). Huitzo dan Abasolo, 28 mil jaraknya, diranking sebagai sangat berbeda gayanya (10 oleh Brainerd-Robinson, 9 oleh Pearson's r). Ketidaksesuaian yang paling menyolok adalah koefisien Huitzo - San Jose Mogote (Plog 1976:269). Mungkin ada dua alasan untuk ini, yaitu alasan statistik dan budaya. Alasan statistik adalah bahwa posisi ranking mungkin menyesatkan ketika dibandingkan dengan koefisien yang sebenarnya. Alasan budaya untuk ketidaksesuaian perlu diuji kembali.

\section{Kemungkinan Penerapannya di Indonesia}

Meskipun studi Stephen Plog mengenai model graviti belum pernah diterapkan di Indonesia. Namun dengan melihat data artefaktual yang melimpah di Indonesia, khususnya artefak tembikar, agaknya dapat diperlakukan sama seperti halnya tembikar di luar Indonesia. Dengan demikian pendekatan model graviti selanjutnya dapat dipelajari kemungkinan penerapannya di Indonesia. Contoh-contoh di bawah ini merupakan satu bukti bahwa penelitian Arkeologi di Indonesia dapat dilandasi oleh model pendekatan tersebut.

Salah satu penelitian yang dimaksud misalnya adalah penelitian tentang motif hias tembikar atau gerabah di situs Gunungwingko (Bantul, DIY), perbandingannya dengan beberapa daerah di Indonesia dan Asia Tenggara. Hiasan gerabah di situs tersebut terdiri atas bermacam-macam pola dan motif hiasan. Beberapa motif dari pola hias tersebut menunjukkan persamaannya dengan beberapa situs di Indonesia sendiri dan beberapa situs di Asia Tenggara, bahkan ditemukan pula di Cina. Beberapa motif lainnya tidak ditemukan persamaannya di daerah-daerah tersebut.

Persamaan motif yang ditemukan di beberapa situs yang lebih tua di Indonesia mungkin merupakan suatu petunjuk bahwa motif Gunungwingko merupakan salah satu kelanjutan dari jangkauan hidup motif tersebut. Persamaan motif yang sejaman dengan situs Gunungwingko mungkin merupakan salah satu petunjuk pula adanya 
interaksi lokal antar penduduk di beberapa daerah Indonesia. Motif hias yang hanya ditemukan di Gunungwingko merupakan bukti adanya variasi atau kreasi lokal yang berkembang di daerah itu sesuai dengan kondisi dan lingkungan daerah tersebut.

Persamaan-persamaan motif hias yang dijumpai di beberapa situs di Asia Tenggara dan daerah lain, mungkin menunjukkan adanya interaksi antar bangsa, sebagai akibat dari aktivitas perdagangan atau dorongan lainnya. Akan tetapi hal itu dapat terjadi pula karena adanya persamaan pola umum (universal pattern) yang melandasi terciptanya suatu kebudayaan.

Demikian studi tentang pola hias gerabah Gunungwingko ternyata dapat diperbandingkan pada konteks daerah yang lebih luas (regional-oriented). Studi ini akan lebih akurat jika menggunakan metode graviti, terutama untuk mengetahui intensitas interaksi masyarakatnya. Studi demikian diharapkan dapat diterapkan pada setiap data, setiap situs dan setiap kurun waktu (masa Prasejarah, Klasik, Islam, maupun kolonial). Sebagai contoh, penelitian untuk mengetahui interaksi antara masyarakat prasejarah masa perundagian baik di situs Anyer (Jawa Barat), Plawangan (Jawa Tengah), Gunungwingko (DIY), maupun Gilimanuk (Bali). Dapat juga studi interaksi masyarakat masa Klasik (Masa Jawa Kuno). Atau penelitian tentang interaksi masyarakat pendukung Masa Islam di Jawa. Dan masih banyak lagi penelitian mengenai studi interaksi masyarakat Kuno maupun primitif di Indonesia yang dapat didekati dengan model graviti.

\section{KEPUSTAKAAN}

Deetz, James F. 1965. The Dynamics of Stylistic Change in Arikara Ceramic. Illinois Studies in Anthropology No. 4. Urbana: University of Illinois Press.

Flannery, Kent V. 1968. The Olmec and the Valley. of Oaxaca: A model for interregional interaction in Formative times. Dumbarton Oaks Conference on the Olmec, edited by E.P. Benson. Washington D.C.: Dumbarton Oaks. Hal. 79--110.

Haggett, P. 1965. Locational Analysis in Human Geography. London: Edward Arnold.

Hill, J.N. 1970. Broken K Pueblo: Prehistoric social organization in the American Southwest. Anthropological Papers of the University of Arizona No. 18. Tucson, Arizona. 
Longacre, W.A. 1964. Sociological implication of the ceramic analisis. Chapters in the prehistory of Eastern Arizona Vol. II. Chicago: Field Museum of natural History. Hal. 155--167.

Longacre, W.A. 1970. Archaeology as anthropology: A case study. Anthropological Papers of the University of Arizona No. 17. Tucson, Arizona.

Morrill, R. 1963. The distribution of migration distances. Papers and Proceedings of the Regional Science Association 11: 75--84.

Olsson, G. 1965. Distance and human interaction: A migration Study. Geografiska Annaler 47B:3--34.

Olsson, G. 1966. Central Place systems, spatial interaction, and stochastic processes, Papers and Proceeding of the Regional Science Association 18:13--45.

Olsson, G. 1970. Explanation, prediction, and meaning variance: An Assessment of distance interaction models. Economic Geography 46:223--233.

Plog, Stephen. 1976. Measurement of Prehistoric Interaction Between Communities. Dalam: K.V. Flannery (ed.). The Early Mesoamerican Village. New York: Academic Press. inc. Hal.255--272.

Renfrew, C. 1969. Trade and Culture Process in European Prehistory. Current Anthropology 10:151--169.

Warren, H. 1969. Tongue: One pueblo's glaze pottery industry dominated middle Rio Grande Commerce. El Palacio 76:36--42.

Wiley, C. 1971. Social Interaction and economic exchange in the Hay Hollow Valley, 900--1200 A.D. Dept. of Anthropology, Field Museum of natural History, Chicago. Mimeograph.

Wright, H.T., dan M Zeder. 1973. The simulation of a linear exchange system under equilibrium conditions. Paper presented at the Annual Meetings of the Society for American Archaeology, San Francisco. Unpublished Manuscript. Museum of Anthropology, University of Michigan. 